DOI 10.22460/infinity.v6i1.238

\title{
THE ENHANCEMENT OF MATHEMATICAL PROBLEM SOLVING ABILITY OF SENIOR HIGH SCHOOL STUDENTS THROUGH QUANTUM LEARNING
}

\author{
Julita \\ Graduate Student of Indonesian Education University, Indonesia \\ julita33@yahoo.co.id
}

Received: September 21, 2016 ; Accepted: January 4, 2017

\begin{abstract}
This study is aimed to examine the quality of quantum learning imfluence toward the enhancement of mathematical problem solving ability of Senior High School students, both viewed entirely and based on mathematical initial ability (MIA) category. In particular, this study is aimed to examine enhancement difference of students' mathematical problem solving ability in a whole and in each level of mathematical initial ability (high, medium and low) between students who receive quantum learning and students who receive conventional learning. This study use experimental quasi with pretests-posttest control group design. Population of this study are Senior High School students in Bogor City. Data is obtained through problem solving ability test and mathematical initial ability data. The result of study showed that students who receive quantum learning have enhancement of mathematical problem solving ability which is higher than students who receive conventional learning. There is no difference enhancement of mathematical problem solving ability both entirely and in each level of mathematical initial ability, except for students with high level of initial mathematical ability.
\end{abstract}

Keywords: Mathematical Problem Solving Ability, Quantum Learning

\begin{abstract}
Abstrak
Penelitian ini bertujuan untuk mengkaji kualitas pengaruh pembelajaran quantum terhadap peningkatan kemampuan pemecahan masalah matematis siswa SMA, baik ditinjau secara keseluruhan maupun berdasarkan kategori kemampuan awal matematis (KAM). Secara khusus, penelitian ini bertujuan untuk mengkaji perbedaan peningkatan kemampuan pemecahan masalah matematis siswa secara keseluruhan dan setiap tingkat kemampuan awal matematis (tinggi, sedang, dan rendah) antara siswa yang mendapatkan pembelajaran quantum dengan siswa yang mendapatkan pembelajaran secara konvensional. Penelitian ini menggunakan metode quasi eksperimen dengan desain kelompok kontrol pretes-postes. Populasi penelitian siswa SMA di Kota Bogor. Data diperoleh melalui tes kemampuan pemecahan masalah dan data kemampuan awal matematis. Hasil penelitian menunjukkan bahwa siswa yang mendapatkan pembelajaran quantum memiliki peningkatan kemampuan pemecahan masalah matematis lebih tinggi daripada siswa yang mendapatkan pembelajaran secara konvensional. Baik secara keseluruhan maupun setiap tingkat kemampuan awal matematis, kecuali siswa dengan tingkat kemampuan awal tinggi tidak terdapat perbedaan peningkatan kemampuan pemecahan masalah matematis.
\end{abstract}

Kata Kunci: Kemampuan Pemecahan Masalah Matematis, Pembelajaran Quantum

How to Cite: Julita (2017). The Enhancement of Mathematical Problem Solving Ability of Senior High School Students Through Quantum Learning. Infinity, 6 (1), 37-50. 


\section{INTRODUCTION}

Problem solving is integral part of mathematics learning process which require students to think. According to Sabandar (2008), thinking process can be triggered and developed through challenging and non routine mathematical problems. In non routine problem, its solution problem need further thinking because its solution procedure is not the same with those taught in class.

Sumiati and Asra (2009) argued that problem solving process give opportunity to students to actively involved in studying, searching, finding by themselves the information to be processed into concept, principle, theory or conclusion. Besides, problem solving is ability to process the information to make decision in problem solving. Student ability in processing information to solve the problem is varied depended on background of student ability in using reasoning, that is ability to see causal effect relation to draw conclusion.

Problem solving ability is ability which shows directed thinking process to ge nerate ideas or develop the possibility to solve problems solved to achieve desired goal (Sumiati and Asra, 2009). According to Santrock (2009), problem solving is finding a right way to achieve a goal. Based on some opinions which had been explained, it can be synthesized that problem solving ability is ability to process information and arrange various alternative of solutions to achieve desired goal. Besides, problem solving is solution of non routine problem and higher level thinking process, and really needed in mathematics learning.

According to Polya (1973), the steps in mathematical problem solving are: understanding the problem, arranging the plan of problem solving, implementing the plan which had been arranged, and rechecking the correctness of problem solving result which had been done. In first step, student should understand clearly the problem faced and it will easier by drawing a picture, diagram, or table of known things.

In next step, student find the relation between given information and unknown information which will enable student to arrange the plan of problem solving. Student can decide the way of problem solving which is suitable and use given information or unknown information to arrange new information.

In third step, students implement the plan which had been arranged in second step, that is implement the problem solving. In implementing the plan, students should check each stage of plan and write the detail which prove that each stage is correct. Students can solve the problem in accord with steps of problem solving they use with correct result. The last step is recheck the steps of problem solving which had been done.

According to National Council of Teachers of Mathematics (NCTM, 2012) that each student has mathematical problem solving ability, if that student is able to apply and adjust various strategies which are appropriate to solve the problem, able to solve the problem occurred in mathematics and everything which involve mathematics in another context, able to build new mathematical knowledge through problem solving, and able to observe and reflect mathematical problem solving.

The process to determine solution of a problem require thinking ability. The ability to collect information and data, express the argument, determine the supporting theory, determine the plot of problem solving is a process which enable students to be able to solve the problem 
(Soekisno, 2015). This is in accord with the goal of problem solving which expect students to have problem solving ability which comprise ability to understand the problem, arrange mathematical model, solve the problem and interpret solution obtained. This presuppose that students should have problem solving ability to master mathematics.

In fact, the result of PISA (Program for International Student Assessment) which measure students mathematical ability in various countries found that the level of mathematical problem solving ability of Indonesian students is very less satisfying (still low). According to Indonesia PISA Center, in 2012 the rank of Indonesia in mathematics field down to $64^{\text {th }}$ of 65 participating countries from $61^{\text {st }}$ rank in 2009. One factor which result in low of Indonesian students' achievement in PISA is lack of problem solving ability in non routine or high level problem.

The study conducted by Ibrahim (2008) also found that mathematical problem solving ability of secondary school and higher education students in Indonesia is still low. Besides, the ability of Senior High School students in mathematical problem solving in Bogor City also had not yet showed satisfying achievement. In Senior High School Mathematics Olympic in Bogor City level, students who occupied top five rank are Senior High School students with high category in Bogor City, This condition shows that mathematical problem solving ability of Senior High School students with medium and low category in Bogor City is still low.

Mathematical problem solving ability which had not meet the expectation shows that students had not been able to develop their thinking ability optimally so mathematical learning process is needed to be improved. Students will not able to solve the problem if they don't posses many concept, theorem or rule from various aspects. Another ability which should be possessed by students in problem solving is ability to identify the problem, namely: what the problem is, where the problem come from, what of type and nature of problem, why the problem is solved, how to solve the problem, and for what aim the problem is solved (Thoifuri, 2008).

The effort to enhance students' mathematical problem solving ability depend on teacher's ability to implement learning process which is effective in school. It is expected that teacher implement learning process which is inspired, enjoyable, challenging, and motivate students to become autonomous learner and capable to solve the problem in their span of life. Teacher needs to do change toward learning process he/she implement.

Teacher habit to implement mathematical learning process which only require students to memorize ways or formulation which had been taught in solving the problem need to be changed. Students do not need to solve the problem with only one way exampled by teacher because it make students' thinking ability not developed and effected on their mathematical problem solving ability. Besides, mathematics learning process had not involved students to participate actively, that is still using lecture method for all learning materials. This makes mathematics become a boring and unpleasant subject.

Learning which can create comfortable and enjoyable atmosphere and which optimize students' problem solving ability is through quantum learning. According to DePorter \& Hernacki (1999), quantum learning is learning which try to create conducive learning atmosphere which is comfortable and enjoyable by combining self confidence, study skill, and communication skill. Quantum learning arise students' interest toward learning by $A M B A K$ (apa manfaat bagiku) or what benefit for me, that is give learning motivation to 
students by choosing mentally between benefit and consequence of decision, and create effective learning environment.

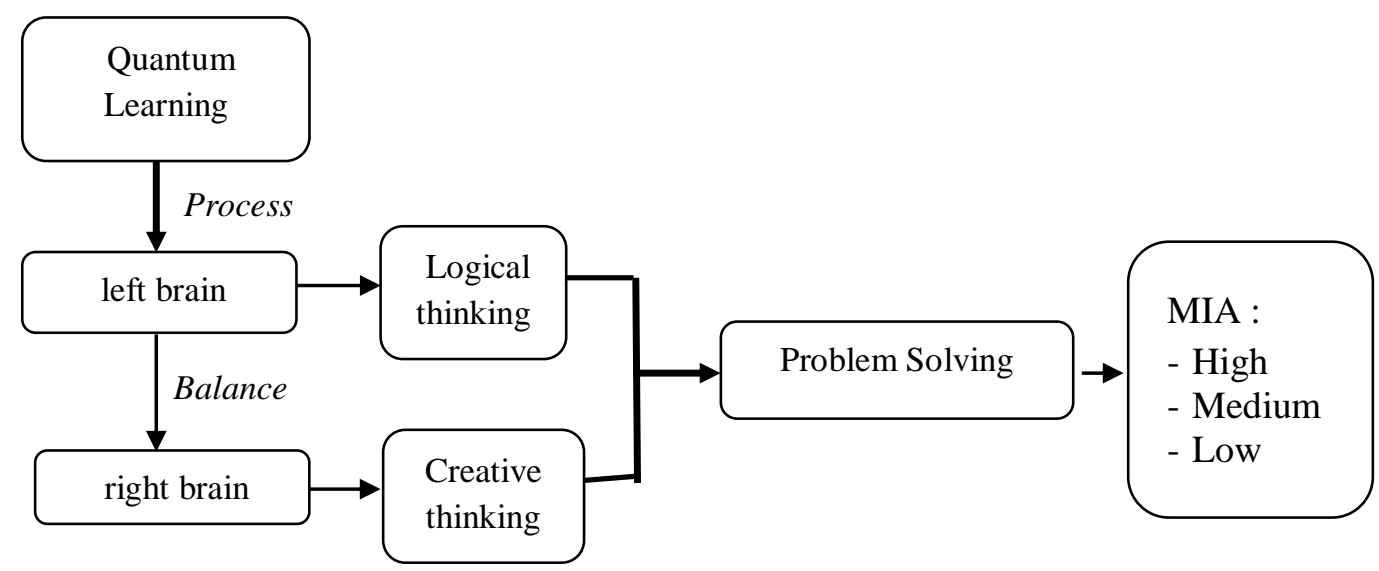

Figure 1. The Scheme Framework of Quantum Learning

Quantum learning process is process of active student learning which balance left brain and right brain which enable students to combine logical thinking and creative thinking. According to dePorter \& Hernacki (1999), the combination of logical and creative thinking is ability needed in mathematical problem solving and ability to process information and arrange various alternative of solutions to achieve the desired goal. The problem solving done is solving the non routine or unfamiliar problem and higher order thinking process, and it is very important in mathematics learning. One's ability in solving the problem depend on potential ability (intelligence) he/she posses (Skinner in Sumiati \& Asra, 2009).

Besides, quantum learning process also maximize the potency of student brain in teaching learning process which is active and contextual by increasing togetherness in enjoyable atmosphere. Learning atmosphere is said enjoyable if it creates communicative and relax learning (Yosodipuro, 2013). The technique which can be done in quantum learning to support this condition can be done by: 1) creating study room which is conducive to build positive suggestive, for example by arranging classroom with good lighting, set background music in class, class wall which is decorated by slogan posters to trigger the spirit, temperature in room which is comfortable, plants placed in classroom, 2) increasing students participation in learning process, 3) teacher not only master teaching material, but also the art which give positive suggestion.

One characteristic of quantum learning is humanistic, that is learning which drive students to learn humanly. According to Hendriana (2012), the characteristic of students who learn humanly is students who learn by building the meaning of mathematics by themselves by using information or knowledge they just acquire. Building the meaning from what is learned by using new information to change, complement or make perfect the understanding which had been inculcated before.

Herbat (in Sumiati \& Asra, 2009) suggested that, before teacher implement learning process, teacher should first know the level of knowledge which had been possessed by students before, because learning as cognitive process is influenced by their initial knowledge. This is in accord with opinion of Ausubel (in Cahyo, 2013) about meaningful learning, that is a 
process to relate new information to existing knowledge in students' cognitive structure and the most important factor influencing learning is students' initial knowledge.

Based on that background, it is needed to conduct the study which aims to examine the enhancement of mathematical problem solving ability of students who are taught by quantum learning and students who are taught by conventional learning viewed from a whole students and based on category of students' mathematical initial ability level (IAL), namely high, medium and low level.

\section{METHOD}

This study is conducted by using experimental quasi with pretest-posttest control group design which involve two groups selected in random, namely experiment group and control group. Pretest is given to two groups before first learning is started, which aimed to enhance level of students' initial ability in mathematical problem solving. Next, posttest is given in final learning (study) which aimed to find out the enhancement of mathematical problem solving ability (PSA) after two groups received learning. Experiment group receive quantum learning, whereas control group receive conventional learning.

To see more deeply the quality of quantum learning influence toward mathematical PSA, this study consider students' mathematical IAL namely high, medium and low level which is taken from the average of daily math test both in experiment class and control class. This study involve three variables, namely independent, dependent, and control. Independent variable consist of quantum learning and conventional learning, whereas students' mathematical PSA is dependent variable. Students' mathematical IAL included in control variable.

Population in this study are all students of class X Senior High School in Bogor City and SMAN 10 is school which is selected as sample of this study with school qualification is non RSBI in Bogor City. The selection of school sample is done in random with lottery method to select one school from seven non RSBI schools. From school which is selected, two classes are taken in simple random as sample of study. This is done because based on information from school staff, the grouping of students in that school not based on ranking. Thus, students' ability in each class is varied. Those two classes which had been selected are selected again to decide experiment class and control class. The class which is selected as experiment class is class X-7 with sample size is 39 students, whereas control class is $\mathrm{X}-8$ with sample size is 39 students. In this case, class which is selected is Class $\mathrm{X}$ based on material tested, namely Three Dimension is learning material which is taught in Class X.

Instrument of study is set of test items and observation sheet whose level of validity, reliability and distinguishing ability and difficulty index had been measured. Instrument used had fulfill validity. Data obtained from this study is quantitative study as analysis toward students' answer for test item of mathematical problem solving ability and is processed by aid of Microsoft Excel and Software SPSS Version 16.0 for Windows Program. Data analysis of study result is done descriptively and inferentially, that is by displaying descriptive data of students' mathematical PSA and its inferential statistic analysis use independent sample t-Test (Mann Whitney Test) in confidence level of 5\%. 


\section{RESULTS AND DISCUSSION}

\section{Results}

The distribution of students in experiment class and control class based on MIA level is presented in Table 1 as follow.

Table 1. The Number of Students in Class of Study Based on MIA Level

\begin{tabular}{ccccc}
\hline \multirow{2}{*}{ Class } & \multicolumn{3}{c}{ Level of MIA } & Total \\
& High & Medium & Low & \\
\hline Experiment & 5 & 27 & 5 & 37 \\
Control & 5 & 30 & 3 & 38 \\
Total & 10 & 57 & 8 & 75 \\
\hline
\end{tabular}

\section{Analysis of Mathematical Initial Ability (MIA) Data}

\section{Descriptive Analysis of Mathematical Initial Ability (MIA) Data}

MIA data is obtained from the average score of daily test in experiment class and control class. This MIA data is taken to find out the equality of students' mathematical ability average in experiment class and control class, and to group students based on their MIA. The description of MIA in this study is presented in data descriptive in Table 2 as follow.

Table 2. Data Descriptive of Students' MIA Based on Learning Approach

\begin{tabular}{clcccc}
\hline & & \multicolumn{3}{c}{ Level of Ability } & \multirow{2}{*}{ Combination } \\
& & High & Medium & Low & \\
\hline \multirow{2}{*}{ Experiment Class } & Sample Size & 5 & 27 & 5 & 37 \\
& Average & 87,50 & 74,24 & 52,00 & 73,03 \\
& Deviation Standard & 3,06 & 3,87 & 7,58 & 10,48 \\
& Sample Size & 5 & 30 & 3 & 38 \\
& Average & 89,00 & 72,75 & 48,33 & 72,96 \\
& Deviation Standard & 3,35 & 5,55 & 5,77 & 10,54 \\
\hline
\end{tabular}

Data in Table 2 shows that the average and deviation standard of students' MIA in each IAL (high, medium and low) for experiment class and control class is relatively the same. As for average and deviation standard of all students for experiment class and control class is relative the same.

Therefore, it can be concluded that the quality of students' MIA in experiment class and control class in each IAL, or all students combined is relatively the same.

\section{Inferential Analysis of Mathematical Initial Ability (MIA) Data}

Inferential analysis of MIA is done to find out the equality of MIA average of all students and each IAL (high, medium and low) between experiment class and control class. The first step before doing equality test of students' MIA average is doing normality test of MIA data in both classes of study based on PSA and its combination. 
The calculation result of data normality test of medium MIA PSA and its combination is showed in Table 3 as follow.

Table 3. Result of Normality Test of MIA Data Based on Medium IAL and Combination of All Samples

\begin{tabular}{llccl}
\hline \multirow{2}{*}{ Group of Sample } & \multicolumn{3}{c}{ Kolmogorov-Smirnov } & \multirow{2}{*}{ Decision } \\
\cline { 3 - 5 } & & db & Sig. & \\
\hline \multirow{4}{*}{ Experiment } & Medium & 27 & 0,000 & reject $\mathrm{H}_{0}$ \\
& Combination & 37 & 0,000 & reject $\mathrm{H}_{0}$ \\
& Medium & 30 & 0,074 & accept $\mathrm{H}_{0}$ \\
& Combination & 38 & 0,040 & reject $\mathrm{H}_{0}$ \\
\hline
\end{tabular}

Result of normality test in Table 3 shows that all pairs of group of students' MIA with medium IAL and its combination have Sig. $<0.05$, so $\mathrm{H}_{0}$ is rejected. This shows that two groups of learning not all normal distributed, so to test the average equality of students' MIA with medium IAL and its combination use Mann-Whitney Test.

The summary of average equality test result of students' MIA from two classes of study based on IAL and its combination is presented in Table 4 as follow.

Table 4. Summary of Average Equality Test Result of Students' MIA from Two Classes of Study Based on IAL and Its Combination

\begin{tabular}{lccccc}
\hline \multicolumn{1}{c}{ Group of Sample } & \multicolumn{2}{c}{$\mathbf{N}$} & $\mathbf{Z}$ & $\begin{array}{c}\text { Asymp. } \\
\text { Sig. }\end{array}$ & Decision \\
& EC & $\mathbf{C C}$ & & $\begin{array}{c}\text { 2-tailled) } \\
\text { (2-tace }\end{array}$ & \\
\hline $\begin{array}{l}\text { Between EC dan CC with } \\
\text { High IAL }\end{array}$ & 5 & 5 & -.775 & .439 & $\begin{array}{c}\text { Accept } \\
\mathrm{H}_{0}\end{array}$ \\
$\begin{array}{l}\text { Between EC and CC with } \\
\text { dengan Medium IAL }\end{array}$ & 27 & 30 & -1.146 & .252 & $\begin{array}{c}\text { Accept } \\
\mathrm{H}_{0}\end{array}$ \\
$\begin{array}{l}\text { Between EC and CC with } \\
\text { Low IAL }\end{array}$ & 5 & 3 & -.769 & .442 & $\begin{array}{c}\text { Accept } \\
\mathrm{H}_{0}\end{array}$ \\
$\begin{array}{l}\text { Between EC and CC } \\
\text { (Combination) }\end{array}$ & 37 & 38 & -.400 & .689 & $\begin{array}{c}\text { Accept } \\
\mathrm{H}_{0}\end{array}$ \\
\hline
\end{tabular}

Annotation: $\mathrm{EC}=$ Experiment Class, $\mathrm{CC}=$ Control Class

In Table 4, it can be seen that Asymp. Sig. (2-tailleds) of two classes of study (combination) is bigger than 0.05 so $\mathrm{H}_{\mathrm{o}}$ is accepted. This means that median of students' MIA pretest in experiment class is not different significantly with median of students' MIA pretest in control class. In other word, students' MIA in experiment class (who receive quantum learning) is not different with students' MIA in control class (who receive conventional learning).

Besides, in Table 4 also it can be seen that Asymp. Sig. (2-tailleds) of each IAL is bigger than 0.05 , so $\mathrm{H}_{0}$ is accepted. This means that median of students' MIA pretest of each IAL in 
experiment class is not significantly different with median of students' MIA pretest of each IAL in control class. In other word, students' MIA of each IAL in experiment class (who receive quantum learning) is not significantly different with students' MIA of each IAL in control class (who receive conventional learning).

Because students' MIA of two classes and students' MIA of each IAL of two classes are not different, then the requirement is fulfilled to give different treatment in each class of study. If there is difference of mathematical PSA in the end of learning, then it is as influence from different treatment in each class and not caused by mathematical ability difference before learning.

\section{Analysis of Mathematical Problem Solving Ability (PSA) Data}

\section{Descriptive Analysis of PSA Data Based on Learning Approach}

Students' mathematical PSA data is obtained from pretest and posttest, then N-gain is calculated. This data is analyzed based on factor of quantum model learning and conventional learning, and mathematical IAL of students with high, medium and low category. Students' mathematical PSA data which is based on learning approach is presented in Table 5 as follow.

Table 5. Data Descriptive of PSA Based on Learning Approach

\begin{tabular}{llccc}
\hline \multicolumn{1}{c}{ Class } & Descriptive Statistic & Pretest & Posttest & N-gain \\
\hline Experiment & Sampel Size & 37 & 37 & 37 \\
& Average & 18,00 & 27,41 & 0,29 \\
& Deviation Standard & 6,41 & 5,01 & 0,11 \\
\multirow{3}{*}{ Control } & Sample Size & 38 & 38 & 38 \\
& Average & 19,89 & 23,89 & 0,14 \\
& Deviation Standard & 6,24 & 6,80 & 0,10 \\
\hline
\end{tabular}

Annotation : maximum ideal score of PSA test is 50

Descriptive statistic data shows that enhancement of students' PSA who receive quantum learning is higher compared to students who receive conventional learning.

In Table 5 it can be seen that PSA pretest average of students who receive quantum learning is 18.00 which is relatively the same with students who receive conventional learning, that is 19.89. After learning process, students' PSA is enhanced. This can be seen from posttest average in students who receive quantum learning which is increased to become 27.41, that is enhanced of 0.29 , whereas students who receive conventional learning is increased to become 23.89, that is enhanced of 0.14. According to Hake (1998), the enhancement of 0.29 and 0.14 is fall in low category.

\section{Descriptive Analysis of PSA Data Based on Learning Approach and Mathematical IAL}

PSA data is based on learning approach and students' mathematical IAL is presented in Table 6. That descriptive statistic data shows that PSA enhancement in all mathematical IAL of students who receive quantum learning is higher than students who receive conventional learning 
Table 6. Descriptive Data of PSA Based on Learning Approach and IAL

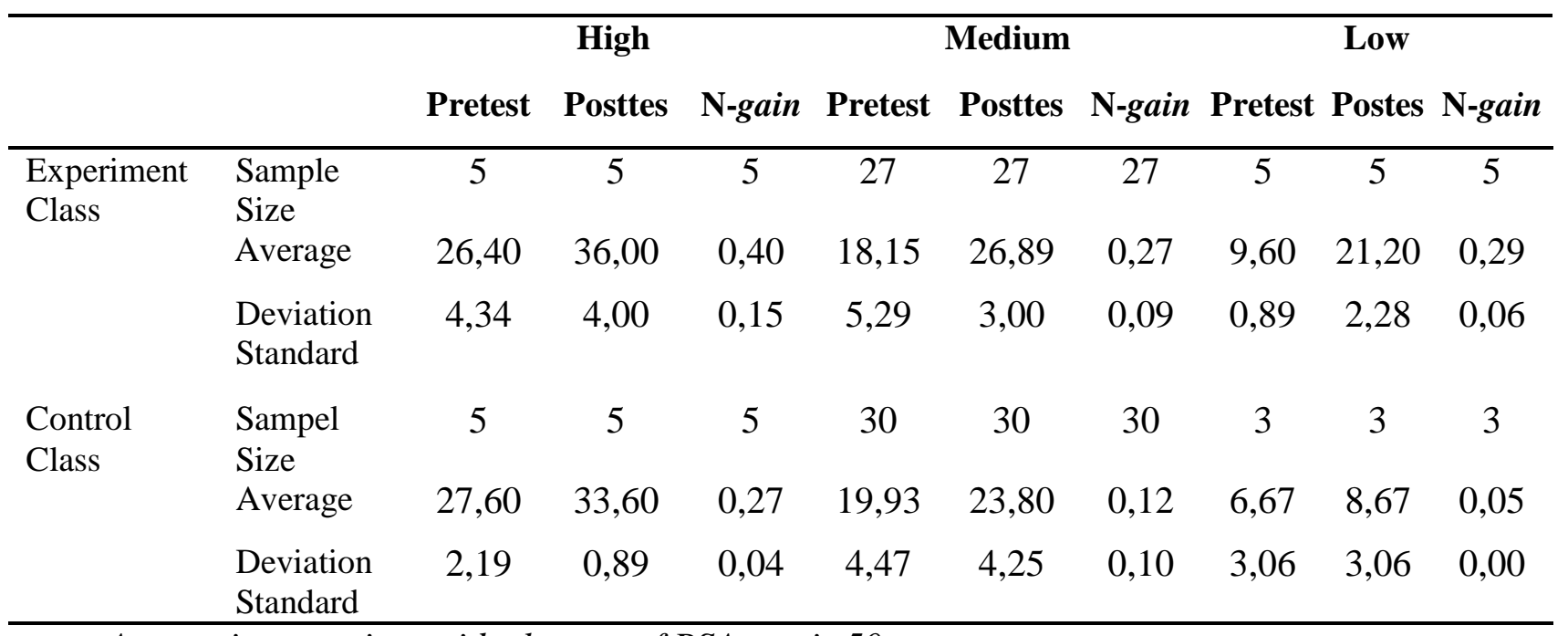

Annotation: maximum ideal score of PSA test is 50

In Table 6, it can be seen that before learning is implemented (pretest data), mathematical PSA for students with high IAL from two classes of study is relatively the same.

After learning is implemented, there is enhancement of mathematical PSA in each level of students' ability. This is happened in experiment class and control class. Learning with quantum model in students with high mathematical IAL has enhancement of 0.40, whereas students with medium and low IAI also has enhancement of 0.27 and 0.29. Mathematical PSA with conventional learning for students with high ability has enhancement of 0.27 , whereas for students with medium and low IAL has enhancement of 0.12 and 0.05 . PSA enhancement of each ability level of students who receive quantum learning and conventional learning is categorized low, except for students with high IAL who receive quantum learning is categorized medium (Hake, 1998).

\section{Inferential Analysis of Mathematical Problem Solving Ability (PSA) Data}

Data analysis of mathematical PSA is continued by statistic test toward difference of PSA enhancement of two groups of learning which is done based on all samples combined and students' mathematical IAL (high, medium and low). Before doing that statistic test, normality test is done first toward data of pretest, posttest and N-Gain of mathematical PSA of two group of learning based on mathematical IAL and combination of all samples as requisite to choose appropriate statistic test. Normality test only done on mathematical PSA of all samples combined and IAL only. This test cannot be dome for data of mathematical PSA with high and low IAL because data available is very little, that is less than 10. Statistic test toward difference enhancement of mathematical PSA with high and low IAL use MannWhitney Test.

Hypothesis of normality test for mathematical PSA of all sample and medium IAL are as follow:

$\mathrm{H}_{0}$ : Data is normal distributed.

$\mathrm{H}_{1:} \quad$ Data is not normal distributed. 
Criteria of hypothesis test based on $\mathrm{p}$-value (sign.), $\mathrm{H}_{\mathrm{o}}$ is rejected if sig. $<\alpha$, for $\alpha=0.05$ and $\mathrm{H}_{0}$ is accepted in another thing. The result of normality test of pretest, posttest and N-gain data which use Kolmogorov-Smirnov is presented in Table 7 as follow.

Table 7. Result of Data Normality Test of Pretest, Posttest and N-Gain of Mathematical PSA Based on Medium IAL and Combination of All Sample

\begin{tabular}{llccccccc}
\hline \multirow{2}{*}{ Group of Sample } & \multicolumn{8}{c}{ Kolmogorov-Smirnov } \\
& & \multicolumn{2}{c}{ Pretest } & \multicolumn{2}{c}{ Posttest } & \multicolumn{2}{c}{ N-gain } \\
& & db & Sig. & Decision & Sig. & Decision & Sig. & Decision \\
\hline Experiment & Medium & 27 & 0,093 & Accept $\mathrm{H}_{0}$ & 0,069 & Accept $\mathrm{H}_{0}$ & 0,200 & Accept $\mathrm{H}_{0}$ \\
& Combination & 37 & 0,068 & Accept $\mathrm{H}_{0}$ & 0,128 & Accept $\mathrm{H}_{0}$ & 0,200 & Accept $\mathrm{H}_{0}$ \\
& & & & & & & & \\
Control & Medium & 30 & 0,179 & Accept $\mathrm{H}_{0}$ & 0,037 & Reject $\mathrm{H}_{0}$ & 0,000 & Reject $\mathrm{H}_{0}$ \\
& Combination & 38 & 0,200 & Accept $\mathrm{H}_{0}$ & 0,169 & Accept $\mathrm{H}_{0}$ & 0,000 & Reject $\mathrm{H}_{0}$ \\
\hline
\end{tabular}

In Table 7, it can be seen that all data have Sig. $>0.05$ which means that $\mathrm{H}_{0}$ is accepted, except for posttest data and $\mathrm{N}$-gain of all samples combined and medium IAL in control class. This shows that mathematical PSA data for two classes of study for all samples combined and medium IAL is normal distributed, except for posttest data and $\mathrm{N}$-gain of all samples combined and medium IAL in control class is not normal distributed.

In the next step, statistic test is done toward PSA pretest data of all samples combined and each students' IAL for two classes of study to find out the equality of its average. For pretest data of all samples combined and medium IAL use Independent Sample t-Test) because two groups of data compared are independent. In Independent-Sample t-Test, there are two value of Significance (Sig.), that is Sig. with assumption that variance of two groups of data compared are homogenous and Sig. with assumption that variance of two groups of data are not homogenous, so homogeneity test needs to done toward each pair of PSA mathematical data from class of study for all samples combined and medium IAL.

Homogeneity test toward variance of two groups of data use Levene Test (Levene Statistic) with hypothesis formulation as follow:

$\mathrm{H}_{0}$ : variance of two groups of homogenous mathematical PSA data

$\mathrm{H}_{1}$ : variance of two groups of non homogenous mathematical PSA data.

The criteria of testing is based on probability value (sig.). $\mathrm{H}_{0}$ is rejected if sig. $<\alpha$, for $\alpha=$ 0.05 and $\mathrm{H}_{0}$ is accepted in another thing. The calculation result of homogeneity test of mathematical PSA data variance for two classes of study based on medium IAL and combination of all samples is presented in Table 8 as follow. 
Table 8. Result of Homogeneity Test of Mathematical PSA Pretest Data Variance for Two Classes of Study Based on Medium IAL and Combination of All Samples

\begin{tabular}{ccccccc}
\hline Initial Ability Level & $\mathbf{N}$ & $\mathbf{F}$ & $\mathbf{d b 1}$ & db2 & Sig. & Decision \\
\hline Medium & 57 & 1,958 & 1 & 55 & 0,167 & accept $\mathrm{H}_{0}$ \\
Combination & 75 & 0,490 & 1 & 73 & 0,486 & accept $\mathrm{H}_{0}$ \\
\hline
\end{tabular}

In table 8 , it can be seen that probability value ( $\mathrm{sig})>0.05$ for medium IAL and combination of all samples, so $\mathrm{H}_{0}$ is accepted. This means that mathematical PSA data between experiment class and control class in medium IAL and combination of all samples have homogeneous variance. After homogeneity test is done, then statistic test is done toward equality of mathematical PSA average in two groups of learning based on IAL and combination of all samples.

Result of equality test of mathematical PSA from two classes of study based on IAL and combination of all samples is presented in Table 9 as follow.

Table 9. Result of Equality Test of Mathematical PSA Average from Two Classes of Study Based on IAL and Combination of All Samples

\begin{tabular}{|c|c|c|c|c|c|c|c|}
\hline \multirow{3}{*}{ IAL } & \multirow{3}{*}{$\mathbf{N}$} & \multicolumn{5}{|c|}{ Statistics } & \multirow{3}{*}{ Decision } \\
\hline & & \multicolumn{2}{|c|}{ Mann-Whitney Test } & \multicolumn{3}{|c|}{ Independen Sample T-test } & \\
\hline & & $Z$ & $\begin{array}{c}\text { Asymp. } \\
\text { Sig. (2- } \\
\text { tailled) }\end{array}$ & 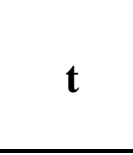 & db & $\begin{array}{c}\text { Sig. } \\
\text { (2-tailled) }\end{array}$ & \\
\hline High & 10 & $-0,110$ & 0,913 & & & & Accept $\mathrm{H}_{0}$ \\
\hline Medium & 57 & & & $-1,380$ & 55 & 0,173 & Accept $\mathrm{H}_{0}$ \\
\hline Low & 8 & $-1,537$ & 0,124 & & & & Accept $\mathrm{H}_{0}$ \\
\hline Combined & 75 & & & $-1,297$ & 73 & 0,199 & Accept $\mathrm{H}_{0}$ \\
\hline
\end{tabular}

In Table 9, it can be seen that probability values (Asymp, Sig and Sig.) > 0.05 for each IAL and combination of all samples, so $\mathrm{H}_{0}$ is accepted. This means that there is significant difference between mathematical PSA average of students in experiment class and control class for each IAL and also combination of all samples. If there is enhancement difference of mathematical PSA in the end of learning, then it is influence of different treatment in each class and not caused by difference of mathematical ability before learning.

Based on information which had been obtained, statistic test is done toward enhancement difference of mathematical PSA toward students of two groups of learning and enhancement difference of mathematical PSA in each students' IAL of two groups. This statistic test use Ngain data of mathematical PSA of students in two classes of study. Based on earlier explanation about data for high and low IAL which is too small and $\mathrm{N}$-gain normality data of medium IAL and combination of all samples, then statistic test is done by using MannWhitney Test.

The summary of test result of mathematical PSA average difference between students from two classes of study based on IAL and its combination is presented in Table 10 as follow. 
Table 10. The Summary of Test Result of mathematical PSA Average Difference of Two Classes of Study Based on IAL and Its Combination

\begin{tabular}{|c|c|c|c|c|c|c|}
\hline \multirow{2}{*}{$\begin{array}{c}\text { No. } \\
\text { Hypothesis }\end{array}$} & \multirow{2}{*}{ Group of Sampel } & \multicolumn{2}{|c|}{$\overline{\mathbf{N}}$} & \multirow{2}{*}{\multicolumn{2}{|c|}{$\begin{array}{c}\text { Asymp. } \\
\text { Sig. } \\
\text { (1-tailled) }\end{array}$}} & \multirow{2}{*}{ Decision } \\
\hline & & EC & $\mathrm{CC}$ & & & \\
\hline 2 & $\begin{array}{l}\text { Between EC and CC with High } \\
\text { IAL }\end{array}$ & 5 & 5 & $-1,293$ & 0,098 & $\begin{array}{c}\text { Accept } \\
\mathrm{H}_{0}\end{array}$ \\
\hline 3 & $\begin{array}{l}\text { Between EC and CC with } \\
\text { Medium IAL }\end{array}$ & 27 & 30 & $-4,597$ & 0,000 & Reject $\mathrm{H}_{0}$ \\
\hline 4 & $\begin{array}{l}\text { Between EC and CC with Low } \\
\text { IAL }\end{array}$ & 5 & 3 & $-2,236$ & 0,013 & Reject $\mathrm{H}_{0}$ \\
\hline 1 & $\begin{array}{l}\text { Between EC and CC } \\
\text { (Combination) }\end{array}$ & 37 & 38 & $-5,158$ & 0,000 & Reject $\mathrm{H}_{0}$ \\
\hline
\end{tabular}

Annotation: $\mathrm{EC}=$ Experiment Class, $\mathrm{CC}=$ Control Class

In Table 10 it can be seen that value of Asymp. Sig (1-tailled) of two classes of study (combination) is smaller than 0.05 , so $\mathrm{H}_{\theta}$ is rejected. This means that median of mathematical PSA N-gain of students with medium and low IAL in experiment class is higher significantly than median of mathematical PSA N-gain of students with medium and low IAL in control class (who receive conventional learning). Besides, in Table 10 also it can be seen that value of Asymp. Sig. (1-tailled) of high IAL is bigger than 0.05 , so $\mathrm{H}_{0}$ is accepted. This means that median of mathematical PSA N-gain of students with high IAL in experiment class is not significantly higher than median of mathematical PSA N-gain of students with high IAL in control class. In other word, it can be concluded that students with high IAL in experiment class (who receive quantum learning) have mathematical PSA enhancement which is higher than students with high IAL in control class (who receive conventional learning).

\section{Discussion}

Based on analysis result of data descriptive, it can be known that the average of mathematical PSA of all students and in each IAL is enhanced, both for experiment class and control class. This shows that implementation of learning in those two classes had been able to stimulate development of students' mathematical PSA. This condition is normal because it is an effect of learning process.

Result of statistic test in Table 10 shows that mathematical PSA of students in all IAL who receive quantum learning is enhanced significantly higher than students who receive conventional learning, except for students with high IAL. Mathematical PSA of students with high IAL is not enhanced significantly compared to students who receive conventional learning. This is because of students with high IAL will ready to receive learning with whatever methods (Sumiati \& Asra, 2009), so there is no significant difference of mathematical PSA enhancement between students with high IAL who receive quantum learning and students who receive conventional learning.

Besides, result of statistic test in Table 10 also shows that mathematical PSA in group of students who receive quantum learning is enhanced significantly higher than group of students who receive conventional learning. This means that in a whole, quantum learning is better in enhancing students' mathematical PSA compared to conventional learning. 
The success of teaching learning process is very influenced by potency of all people involved and interaction created in class. The higher of potency of all people involved and the more optimal of interaction activity in learning process with conducive and enjoyable atmosphere, then the higher will be the effectiveness of teaching learning process occurred. According to Reigeluth (Uno, 2007), the effectiveness of teaching usually measured by level of students' achievement in teaching goal which had been determined.

\section{CONCLUSION}

Based on data analysis and discussion of study result in earlier chapter, the conclusions are obtained as follow:

1. The enhancement of mathematical PSA in students who receive quantum learning is higher than students who receive conventional learning.

2. The enhancement of mathematical PSA in students with medium and low IAL who receive quantum learning is higher than students who receive conventional learning. Whereas, there is no significant difference of mathematical PSA enhancement between students with high IAL who receive quantum learning and students who receive conventional learning.

\section{REFERENCES}

Cahyo, A. N. (2013). Panduan Aplikasi Teori-Teori Belajar Mengajar Teraktual dan Terpopuler. Yogyakarta: DIVA Press.

DePorter, B., \& Hernacki, M. (1999). Quantum Learning: Membiasakan Belajar Nyaman dan Menyenangkan. Bandung: Penerbit Kaifa.

Hake, R. R. (1998). Interactive Engagement Versus Traditional Methods: A Six-ThousandStudent Survey of Mechanics Test Data for Introductory Physics Courses. American Journal Physics, 66, 64-74.

Hendriana, H. (2012). Pembelajaran Matematika Humanis dengan Metaphorical Thinking Untuk Meningkatkan Kepercayaan Diri Siswa. Infinity, 1(1), 90-103.

Ibrahim. (2008). Pembelajaran Matematika untuk Meningkatkan Kemampuan Pemecahan Masalah Matematis Siswa Sekolah Menengah Atas. Jurnal Pendidikan Matematika, 2, 90-99.

NCTM. (2012). 2011-2012 NCTM Program Report of SPA Assessments. Reston, VA: The National Council of Teachers of Mathematics Inc.

Polya, G. (1973). How To Solve it: A New Aspect of Mathematical Method. New Jersey, USA: Princeton University Press.

Sabandar, J. (2008). Thinking Classroom dalam Pembelajaran Matematika di Sekolah. Simposium Internasional. Bandung: Universitas Pendidikan Indonesia.

Santrock, J. W. (2009). Psikologi Pendidikan. Jakarta: Penerbit Salemba Humanika.

Soekisno, R. B. (2015). Pembelajaran Berbasis Masalah untuk Meningkatkan Kemampuan Argumentasi Matematis Mahasiswa. Infinity, 4(2), 120-139.

Sumiati, \& Asra. (2009). Metode Pembelajaran. Bandung: CV Wacana Prima.

Thoifuri. (2008). Menjadi Guru Inisiator. Semarang: RaSAIL Media Group. 
50 Julita, The Enhancement of Mathematical Problem Solving Ability ...

Uno, H. B. (2007). Model Pembelajaran Menciptakan Proses Belajar Mengajar yang Kreatif dan Efektif. Jakarta: PT. Bumi Aksara.

Yosodipuro. (2013). Siswa Senang Guru Gemilang. Strategi Mengajar yang Menyenangkan dan Mendidik dengan Cerdik. Jakarta: PT. Gramedia Pustaka Utama. 